\title{
The Interlibrary Loan Service of the National Library of Medicine
}

\begin{abstract}
Both the new quarters of the NLM and the legal basis upon which it operates facilitate interlibrary lending. NLM's liberal lending policies were formulated in 1957, and use of the service has grown very rapidly since that time. In order to speed up the furnishing of photocopies in lieu of loans, cameras are now moved throughout the stack rather than the materials brought to a filming center. Through these activities, NLM is attempting to fulfill the role of "a national backstop to local library resources" in medical and related fields.
\end{abstract}

T he National Library of Medicine is known in the United States and throughout the world as the institution preeminently concerned with the acquisition, organization, storage, retrieval, and dissemination of the published literature of the medical sciences.

The administrative history of the library is inscribed on the verso of an imposing, dark green granite wall at the entrance of the new building. It reads as follows:

"Founded in 1836 as the Library of the Surgeon General's Office, United States Army; developed as a national resource under the leadership of John Shaw Billings, Librarian from 1865 to 1895; named Army

$D r$. Roe is chief, reference services division, National Library of Medicine, and Mr. Cassidy is head, loan and stack section, reference services division, National Library of Medicine. This paper was presented as part of a panel discussion on the Federal Government and College Libraries, before the College Libraries Section of ACRL at the ALA Conference in Saint Louis, Missouri, June 30, 1964.
Medical Library in 1922 and Armed Forces Medical Library in 1952; made a part of the Public Health Service of the Department of Health, Education, and Welfare in 1956; established on this site in 1961; the one hundred and twenty-fifth anniversary of its founding."

In April of 1962 the library moved into its new home at the southeastern corner of the Bethesda, Maryland, campus of the National Institutes of Health. During two extremely busy years of suburban bibliometamorphosis the library has sought to strengthen and expand its various services. The services of the library range from conventional reference and bibliographic work to the new computer based MEDLARS program, which will not only automate the publication of Index Medicus but will provide customized units of bibliographic information on recurring and demand bases. This paper, however, will be limited to a detailed review of the interlibrary loan program, since college libraries use this service more than any other offered by the library. 


\section{Legislative Authority}

Under Section 372 ("Functions of the Library") of Public Law 941 (84th Congress), the National Library of Medicine Act, the following legal base for the library's interlibrary loan program is provided:

"Sec. 372. (a) The Surgeon General, through the Library . . . shall . . . make available, through loans, photographic or other copying procedures or otherwise, such materials in the library as he deems appropriate. ..."

On August 3, 1956, the President signed into law the National Library of Medicine Act. Following this action the library began an internal review of various activities, including those of the interlibrary loan and photoduplication services.

\section{LOAN POLICY}

In September 1957 the National Library of Medicine initiated a new loan policy. ${ }^{1}$ This new program included four important features:

1. The National Library of Medicine lent material only to other libraries. Individuals could use library materials on the premises, but could neither remove them from the library nor borrow them in any form by direct request. The operation thereby became an interlibrary loan service in name and in fact.

2. Although all printed literature in the library's collection was available for loan, the decision to lend depended on a number of factors. It was felt that NLM should provide only supplementary service to local and regional libraries. Ordinary, current, intrade publications considered to be of widespread accessibility were not subject to loan in any form.

${ }^{1}$ Frank B. Rogers, "The Loan Policy of the National Library of Medicine," Bulletin of the Medical Library Association, XLV (October 1957), 486-93.
3. The NLM reserved the right to determine whether the loan was made in the original or as a photoduplicate (microfilm or photoprint). This determination was based on the photocopying costs, copyright restrictions, rarity and physical condition of the item requested, shipping costs, and any other pertinent factors.

4. Photoduplicates sent instead of original material were supplied free of charge to requesting libraries. Such photocopy could be retained permanently by the borrowing library.

It was felt that the introduction of an interlibrary loan program in accordance with these new policies would not only be more effective but would also be less expensive to maintain and enlarge. Experience to date has confirmed these assumptions. Accordingly, the basic features of the loan policy of 1957 remain in effect at this time (see appendix).

\section{INTERNAL OPERATIONS}

The processing routines of the interlibrary loan operation have been streamlined. The microforms and photostats provided prior to 1957 have been largely replaced by Xerox photoprints. With the move to a new building in April 1962, came the opportunity to introduce a unique photoloan procedure. This operation had to be geared to handle efficiently an average of seven hundred loans per day with midweek peaks as high as one thousand loans per day.

Under the old system books had been carried from the shelves to a centralized group of microfilm cameras. This involved temporary loss of material while it was in the pipeline and required multiple sorting and reshelving operations. Under the new plan roving cameras were designed for use in the stack aisles. Electric feedrails were installed in the aisle ceiling, permitting five mobile cameras to negotiate the aisles like trol- 
ley cars. Books are now brought to specially designated shelves at the end of each range. They are then photographed, returned to the special shelf, and finally replaced at their proper position in the range. Exposed microfilm is developed overnight and processed the next day by a Copyflo printer capable of replicating thirty-two pages of text per minute. These new procedures have introduced greater efficiency and economy into the loan operation, permitting an orderly adjustment of the service to rapidly expanding processing loads.

\section{College and University LOANS}

A recent survey ${ }^{2}$ of the NLM interlibrary loan operation included an analysis of various types of borrowing libraries. The general, nonmedical libraries of colleges and universities (including departmental libraries as well as libraries serving nonmedical graduate schools) accounted for only 4.12 per cent of total loans in the United States and 6.75 per cent of all loans to foreign countries. Application of these percentages to the fiscal year 1963 photocopy interlibrary loan rates yields a college and university library rate of approximately six thousand such loans.

Though the bulk figure is more impressive than the percentage, these statistics suggest that the demands of college and university libraries for NLM loan service are reasonable. It is possible that the biomedical loan requirements of colleges are being met by local and regional resources, such as those of medical school, medical society, and public libraries. Or perhaps some college librarians are not yet fully aware of NLM services or do not realize that these services are extended to libraries other than medical. Medicine is a broad field and the collection is an inclusive one, with

\footnotetext{
2 William H. Kurth, Survey of the Interlibrary Loan Operation of the National Library of Medicine (Washington: 1962), 49p.
}

materials on such subjects as-and this is only a sampling-psychology, anthropology, artistic anatomy, and sanitary engineering. So it may be that this paper will open for some a so-far-unrealized source for legitimate loan activity.

\section{The NLM as a National Backstop}

As Windsor lecturer for 1963 at the University of Illinois, Verner W. Clapp dealt with the theme, "The Future of the Research Library." 3 He characterized the National Library of Medicine as "the most conspicuous example of a national backstop to local library resources in a specific subject." The three essential elements of a national member of the research library system are considered to be "comprehensive acquisition within a conspicuous subject field; publication of the principal current bibliography of that field; and the obligation to backstop local resources in that field." Mr. Clapp considers that the NLM is an outstanding example of such a library.

\section{Statistics}

A review of the interlibrary loan statistics for fiscal year 1963 provides quantitative confirmation of the magnitude of the NLM backstopping operation. Requests for interlibrary loans totaled one hundred fifty-eight thousand, an increase of 22.5 per cent over the previous year. One hundred thirty-five thousand or 86 per cent of these requests were filled by either photocopy (one hundred twenty-eight thousand) or original materials (sixty-five hundred). In the case of photocopy orders alone this amounted to filling such requests at a rate of over one per minute of every working day throughout the year. Through this mechanism, some two thousand libraries around the world received approximately two million three hundred thousand

\footnotetext{
Verner W. Clapp, The Future of the Research Library. (Urbana: Univ. of Illinois Press, 1964), $114 \mathrm{p}$.
} 
pages of photocopy. One in eight of these photoloans was sent to a foreign library to whom the NLM represents a primary international resource.

\section{A National Problem}

In spite of this impressive evidence of the sharing efforts of NLM, there must be equally strong efforts to develop programs of local self-sufficiency. Recognition that the NLM collections, consisting mainly of single original copies, cannot meet the multiple needs of reader service, interlibrary loan, and resource development on a national and international basis is becoming painfully apparent. In a recent editorial ${ }^{4}$ the editor of the Bulletin of the Medical Library Association stated, "With fine medical research collections in almost every region of this country, it seems ludicrous that medical libraries of every size in every part of the nation should think of

4Alfred N. Brandon, "A National Problem," Bulletin of the Medical Library Association, LII (April 1964) 442.

\section{MUSIC MANUSCRIPT}

(Continued from page 16)

For the Burgundians: Bodl. Li. MS Can. Misc. 213, “Canonici."57

For late fourteenth and early fifteenthcentury English sacred music: Catholic College of St. Edmund, Old Hall, England, "Old Hall MS." 58

The most important single source of fifteenth-century music are the Trent Codices from the library at Trent. They contain more than sixteen hundred pieces, dated between ca. 1420 and ca. 1480,

\footnotetext{
${ }^{57}$ Secular pieces transcribed: John Stainer, Dufay and His Contemporaries (London \& New York: Novello, 1898). Sacred pieces in Charles van den Borren, Polyphonia Sacra (London: Plainsong and Medieval Music Society, 1932).

58 New 3-volume edition by A. Ramsbotham (Burnham \& London: Plainsong and Medieval Music Society, 1933-38). The reader who cares to see how such manuscripts are analyzed by musicologists can find no better specimen of the technique than Manfred Bukofzer's essay on the Old Hall Manuscript, in his Studies in Medieval and Renaissance Music (New York: Norton, 1950).
}

borrowing any journal directly from the National Library of Medicine instead of seeking it first within their own areas. ... Let us use the services of our NLM correctly and in perspective, so as to assure everyone better service in obtaining unique material or receiving reference aid that cannot be supplied locally."

Planning for appropriate measures of regional and local self-sufficiency is the next task to which the National Library of Medicine and the medical library profession must address themselves. Provision of medical library service adequate to meet the needs of burgeoning medical investigation-and adequate to the requirements of related disciplines which come through nonmedical libraries-requires the reinforcement of the national network of library services through which local resources are supplemented by regional libraries. To such a network, the National Library of Medicine can truly, to use Mr. Clapp's term, act as a "national backstop."

by about seventy-five British and continental composers. ${ }^{59}$

Contemporary Literature on Music. The chief writings are the "Ars Nova" of Vitry; ${ }^{60}$ the pro-Vitry "Ars Novae Musicae" and other works by Jean de Muris (d. ca. 1351); ${ }^{61}$ the "Speculum Musicae" by Jacob of Liège, a virtual encyclopedia of medieval musical learning, ending with an attack on the new music of Vitry and Muris and a defense

(Continued on page 60 )

\footnotetext{
59 For transeriptions see volumes 7, 11, 14, 27, 31 and 40 of the 83-volume Denkmäler der Tonkunst in Osterreich (Vienna: Universal, 1894-1938). There is a diseussion of the Codices with bibliography in Harvard Dictionary, pp.759-60.

co Text in Coussemaker, Scriptorum, III, 13-22 ; English translation by Leon Plantinga, Journal of Music Theory, V-2 (November 1961), 204-23.

a Treatises printed in Gerbert, op. cit., III, 189318: partial translation into English in Strunk, op. cit., pp.172-79; discussion by $H$. Besseler in Archiv fur Müsikwissenschaft, VIII (1926), 207-09, centering on text collations.
} 